\title{
Conquest and Incorporation: Pays Conquis or Pays Réunies?
}

\begin{abstract}
This chapter investigates how the (nominally) independent states in the Netherlands and Northwest Germany were slowly but surely seized by French troops, and subsequently incorporated by imperial decree. The conquest and incorporation of the northern lands brought about radical political changes, as well as dilemmas. How were new territories to be fitted in: as dependencies taken by force (pays conquis), or as new departments on equal footing (pays réunies)? And to which extent did 'on equal footing' mean eradicating regional diversity within the Empire? Whether uniform structures were imposed too promptly, or not, was contested. The Emperor sent confidants northbound, to investigate existing conditions. Vice versa, Northerners visited Paris, to exert influence on the status of their projected departments. For Dutch and German dignitaries it was of the utmost importance to acknowledge Napoleon's droit de conquête, while lobbying for an integration form that did justice to local circumstances. Eventually, both areas were given a full status within the Empire, taking into account national peculiarities to a certain extent, but only as long as that did not harm the interests of Old France.
\end{abstract}

Keywords Right of war $\bullet$ Conquest $\bullet$ Incorporation $\bullet$ Imperialism 


\section{Between Coercion and Cooperation}

Although Napoleon, during his final years exiled on Saint Helena, stressed the civic gains of his rule, such as his legal heritage, most Europeans vividly remembered the intrusion of military aspects in dayto-day life as a defining feature of the Napoleonic state. Enlargement of Empire was not seldom preceded by warfare, with disastrous effects for the local populations. However, the transition to 'modern' governance in Europe (equating 'modernization' with 'Francization') would have been more difficult without preparatory work by the military. Significantly, military officials increasingly received governing tasks, which blurred the lines between civil and military aspects of Napoleonic governance. ${ }^{1}$ The conquest and incorporation of present-day Belgium and the German Rhineland had shown the French how foreign territories could be integrated into their state. Whereas the French Directory was led by the belief that Greater France had clear natural limits (in the north, the river Rhine), during the Consulate, after a brief period of consolidation, the French again looked beyond their borders. As Napoleon's might grew, so did his desire for interventions in Dutch and Northwest German matters.

Transitions from one government to another, driven notably by international political considerations, coupled with the growing prominence of the Napoleonic system of governance. Its gradual introduction conflicted with local conditions. Age-old governing practices and the legitimacy of administrative traditions were challenged by the French. The establishment of the Empire in 1804 intensified this process, eventually leading to the construction of the Kingdom of Holland and the dissolution of the Holy Roman Empire. A general wish for a stable, albeit less 'democratic', organization of state and society facilitated (coerced) acceptance of the Napoleonic system of governance. Cooperation appeared to be the most productive way of satisfying different actors' needs under the given circumstances. For pragmatic reasons, attempts were made to render the French model applicable to Europe, which did not mean that extant ways of governing were easily put aside. This chapter shows how the Netherlands

\footnotetext{
${ }^{1}$ Alan Forrest, 'La guerre, les perceptions et la construction de l'Europe', in: F. Antoine et al. ed., L'Empire napoléonien. Une expérience européenne? (Paris 2014) 84-96.
} 
and Northwest Germany lost the remainders of their independence, focusing on ideas about the status that the new areas should be given within the Empire.

\section{EMPERORS AND KINGS}

On 18 May 1804 the French Empire was proclaimed via sénatus-consulte. Bonaparte, thanks to his charisma and successful propaganda, was seen by many as a guarantee of law and order. Two years earlier he had been proclaimed Consul for life. Significantly, Article 55 of the 1802 Constitution had already stipulated that Napoleon, when circumstances required, could place departments 'outside' the Constitution, which could be used to treat incorporated departments in a different manner. Proposals and support of the legislative chambers gave an air of legality to the gradual transition from republic to Empire. During the enlargement of Revolutionary France, the term 'empire' had come into use to designate French hegemony. Also, General Bonaparte became presented as imperator, a title awarded by the Romans to victorious generals. With Napoleon's installation as Emperor, a new political constellation was created which combined revolutionary achievements with concepts from the ancien régime. ${ }^{2}$

The new imperial constitution did not bring much change to the executive, apart from a (theoretical) strengthening of the control of the Senate. ${ }^{3}$ However, one truly new feature of the new constitution would later affect the way in which Napoleon shaped his Empire, namely the introduction of the grandes dignités de l'Empire, the Grand Dignitaries, many of whom would later play a role in the enlargement of the Empire. Theses honorific titles where bestowed on important men in the close circle of Napoleon, such as his brothers (in-law). They received some (representative) tasks, notably archichancelier Jean-Jacques-Régis de Cambacérès, who replaced Napoleon in official meetings was in the absence of the Emperor. ${ }^{4}$ Former Third Consul Charles-François Lebrun was appointed architrésorier.

${ }^{2}$ Annie Jourdan, 'Le Premier Empire: un nouveau pacte social', Cités (2004) 51-64. https://doi.org/10.3917/cite.020.0051

${ }^{3}$ Aurélien Lignereux, L'Empire des Français: 1799-1815 (Paris 2012) 86.

${ }^{4}$ Nicole Gotteri, Grands Dignitaires, Ministres et Grands Officiers du Premier Empire. Autographes et notices biographiques (Paris 1990) 10. 
In 1805 the French government asked the Batavian ambassador in Paris, Rutger Jan Schimmelpenninck, to draft a new constitution and become Raadpensionaris (Grand Pensionary) of the Batavian Commonwealth. 'President' Schimmelpenninck's reign left little room for popular sovereignty, but it was a guarantee for the Batavian autonomy, which was still the most important consideration. Moreover, Napoleon did not support a direct copy of the French constitution either in 1801 or in 1805. He was convinced, on the one hand, that the Dutch national identity was too different from the French, and on the other hand, that he had an interest in letting the European powers continue to regard the Batavian Republic as an independent state. ${ }^{5}$ Schimmelpenninck appointed both moderate and radical revolutionaries to prominent positions, among them Alexander Gogel as Minister of Finances. One of his achievements was the introduction of new fiscal legislation, drawn up by Gogel, which entailed economic reforms in the spirit of the revolution. A notable success was the creation of a new system of primary education, based upon progressive pedagogical ideas. Both reforms would be long-lasting. ${ }^{6}$

Soon after, being dissatisfied with Rutger Jan Schimmelpenninck, Napoleon decided the Batavians had to 'invite' his brother Louis to become king. The foundation of the Kingdom of Holland was fraught with difficulties: a centuries-old republic, with a strong tradition of decentralized institutions, had to be transformed into a hereditary monarchy. During the negotiations in Paris between the Batavians diplomats and Charles-Maurice de Talleyrand, the Dutch had already argued that monarchy was incompatible with Dutch national identity. Louis Bonaparte was certainly no enthusiast of republicanism, and convinced that monarchy was a superior form of government. Louis stressed that the Dutch had to be persuaded to accept monarchism. He believed his government could unify the Dutch nation. ${ }^{7}$ Given the poor circumstances, Louis Bonaparte's

\footnotetext{
${ }^{5}$ Martijn van der Burg, Nederland onder Franse invloed. Culturele overdracht en staatsvorming in de napoleontische tijd, 1799-1813 (Amsterdam 2009). Cf. https://hdl.handle. net/11245/1.272472

${ }^{6}$ Matthijs Lok and Martijn van der Burg, 'The Dutch case: The Kingdom of Holland and the imperial departments', in: M. Broers, P. Hicks and A. Guimerá ed., The Napoleonic Empire and the new European political culture (Basingstoke 2012) 100-111. https://doi. org/10.1057/9781137271396_10

${ }^{7}$ Martijn van der Burg, 'Transforming the Dutch Republic into the Kingdom of Holland: The Netherlands between republicanism and monarchy (1795-1815)', European Review of History 17 (2010) 164-165. https://doi.org/10.1080/13507481003660811
} 
reign was rather effective. By authoritarian means, he implemented and consolidated many reforms which dated from the revolutionary era, such as national cultural institutions. Also, he initiated new reforms, such as the codification of civil law, and introduced French institutions, and uniformity in subnational administration. Often, French examples and Dutch tradition were aligned. ${ }^{8}$ Against all odds, Louis' monarchy functioned, albeit not in the way the Emperor wished.

Simultaneously, Napoleon was initiating considerable transformations in Germany. In theory, most German lands still formed part of the Holy Roman Empire, but in actual fact, the age-old Empire was a hollow shell. Anticipating the dissolution of Germany, the Habsburg Emperor Francis II had created the Austrian Empire out of his Central European lands in 1804. Napoleon had further rendered the Holy Roman Empire irrelevant by creating the Confederation of the Rhine, consisting of 16 sovereign German states, of which he became the 'Protector'. Within two years, the Confederation doubled in member states. ${ }^{9}$ Emperor Francis II abdicated on 6 August 1806, which signified the dissolution of the Holy Roman Empire.

Between 1795 and 1805 Prussia had remained a neutral power. In return, Napoleon supported Prussian territorial growth in the East. However, internal power struggles, and growing problems with other states, led to escalation. Moreover, it became clear during peacenegotiations that Napoleon was willing to return Hannover to the British crown, even though Prussia had annexed Hannover. On 26 September 1806, Frederick William III presented Napoleon with an ultimatum: French troops should leave German lands north of the Rhine immediately. But within three weeks, on 14 October, the inferior Prussian armies were defeated at Jena and Auerstedt (by Marshal Davout, the later Governor in Hamburg). People in Northwest Germany realized that now France could do as it pleased. The following year, Prussia was forced to sign the

\footnotetext{
${ }^{8}$ Martijn van der Burg, 'Cultural and legal transfer in Napoleonic Europe: Codification of Dutch civil law as a cross-national process', Comparative Legal History 3 (2015) 85-109. https://doi.org/10.1080/2049677X.2015.1041727

${ }^{9}$ Michel Kerautret, 'Les Allemagnes napoléoniennes', in: T. Lentz ed., Napoléon et l'Europe (Paris 2005) 330-331.; Bernhard Struck and Claire Gantet, Revolution, Krieg und Verflechtung, 1789-1815 (Darmstadt 2008) 103.
} 
humiliating Peace of Tilsit; all territories in Northwest Germany came into French hands. ${ }^{10}$

On 21 November 1806, exactly one year after the destruction of the French-Spanish fleet at Trafalgar, which had made Great Britain the dominant naval power, Napoleon implemented the Blocus continental (Continental System). The Continental System is essential for a proper understanding of Napoleon's European politics. In essence, this trade embargo against Britain was a form of commercial warfare. Napoleon legitimized the Blocus by his interpretation of the droit de guerre, or droit de conquête. ${ }^{11}$ Although Napoleon often considered himself to be above the law, or at least was able to interpret legislation as he pleased, ${ }^{12}$ he did give weight to law during wartime, the jus in bello, and incriminated the British. His dominance on land was legitimized by (his conception of) the law of war. French troops respected the jus in bello, he claimed. In contrast, Great Britain was supreme on sea and therefore, in his view, did not adhere to the law of nations, as maritime dominance violated the freedom of the seas. ${ }^{13}$

Thus, Napoleon gave a new meaning to commercial warfare. Gradually, the Continental System was forced upon many peoples that did not belong to the Empire or states ruled by the Bonaparte family. Secondly, the Continental System had a distinctly offensive character. Eventually, all ships having stopped over in British ports, as well as their cargo, were confiscated, regardless of their nationality, as the Emperor considered them to be 'denationalized'. ${ }^{14}$ Apart from that, the Continental System can also be seen as an attempt to create a common European market of which the Empire could benefit. By boycotting British imports, Napoleon believed France could become the main economic center in Europe. But he probably overestimated the fragility of the British economy. ${ }^{15}$

\footnotetext{
${ }^{10}$ Jeroen Koch, Koning Willem I, 1772-1843 (Amsterdam 2013) 165-168; Struck and Gantet, Revolution, Krieg und Verflechtung, 103-104.

${ }^{11}$ Silvia Marzagalli, 'Le Blocus continental pouvait-il réussir?', in: T. Lentz ed., Napoléon et l'Europe (Paris 2005) 103-105.

${ }^{12}$ Donald R. Kelley, 'What pleases the prince: Justinian, Napoleon and the lawyers', History of Political Thought 23 (2002) 288-302.

${ }^{13}$ Bruno Colson, Napoleon on war (Oxford 2015) 28, 38.

${ }^{14}$ Silvia Marzagalli, 'Napoléon, l'Europe et le blocus continental. Application et réactions à partir de l'étude de trois villes portuaires: Bordeaux, Hambourg et Livourne', in: J.-C. Martin ed., Napoléon et l'Europe. Colloque de la Roche-sur-Yon (Rennes 2002) 71-90.

${ }^{15}$ Martijn van der Burg, 'Napoleonic wars', in: K. Hendrickson ed., The encyclopedia of the industrial revolution in world history 3 (New York 2015) 657-659.
} 
With the dissolution of the Holy Roman Empire, the question arose of what to do with the former free imperial cities. Legally, they had become sovereign states, but the new French Empire was to take over the constitutional void. ${ }^{16}$ Hoping to preserve their independence, the Hanseatic towns joined forces and formed the Hanseatic federation. However, soon after, French troops took control of Lübeck, Bremen, and Hamburg. ${ }^{17}$ In the South of Germany, the free imperial cities were awarded to Napoleon's allies: Augsburg and Nuremberg to the new Kingdom of Bavaria; Frankfurt am Main to the Principality of Aschaffenburg. Bremen, Hamburg, and Lübeck however, received the status of pays réservé, a territory of which the future status was still undecided. Merging the towns and their surroundings into a single North German member state of the German Confederation was highly probable. ${ }^{18}$

Concurrently, Napoleon decreed a territorial restructuring of newly conquered Prussian lands between Rhine and Elbe. In the interim, the territories were reshuffled into five temporary administrative units, headed by a gouverneur or gouverneur général - as Napoleon tended to designate the Governors. Like the Hanseatic cities, the lands became pays réservés. The Governors, all generals, administrated from the towns of Braunschweig, Erfurt, Minden, Münster, and Fulda (taken from Dutch Prince William Frederick who had sided with his Prussian family members). Each was aided by an intendant who oversaw financial matters. Next to the pays réservés established on 23 October 1806, there were many more, some very short-lived, pays réservés in this period. ${ }^{19}$ Subsequently, as part of the creation of a new European state system, the Grand Duchy of Berg and the Kingdom of Westphalia were established. Both were mergers of the above-mentioned former bishoprics, Prussian territories or other minor (ecclesiastical) states.

\footnotetext{
${ }^{16}$ Barbara Dölemeyer, 'Frans recht in Noord-Duitsland. De inlijving van de noordwestelijke gebieden van Duitsland bij het Franse keizerrijk', in: A. Berkvens, J. Hallebeek and A. Sirks ed., Het Franse Nederland: de inlijving 1810-1813. De juridische en bestuurlijke gevolgen van de 'Réunion' met Frankrijk (Hilversum 2012) 35, 41.

${ }^{17}$ Katherine Aaslestad, 'Lost neutrality and economic warfare. Napoleonic warfare in Northern Europe, 1795-1815', in: R. Chickering and S. Förster ed., War in an age of revolution, 1775-1815 (Cambridge 2010) 379-380.

${ }^{18}$ Swantje Naumann and Helmut Stubbe da Luz, Die französischen Besatzer in Hamburg. Zeugnisse zu den Jahren 1811-1814 (Hamburg 2013) 31.

${ }^{19}$ Annie Jourdan ed., Correspondance générale. Tome dixième. Un Grand Empire, mars 1810-mars 1811 (Paris 2014) annexes.
} 
Not respecting historical borders, new administrative entities were created, meanwhile abolishing traditional corporations and feudal privileges. So-called intendants were appointed and studied extant systems of governance. Like in France, newly created departments received names based on mountains or rivers. ${ }^{20}$ Certainly 'model state' Westphalia, ruled by Jérôme Bonaparte, had to serve as a positive example of Napoleonic governance in Germany. Jérôme, however, was unable to meet the high expectations of Napoleon, who came to prefer the more efficient system of the Grand Duchy of Berg, which was ruled by Marshall Joachim Murat. ${ }^{21}$ Both new Napoleonic states were influential concerning the implementation of Napoleonic governance after 1810 since they bordered, and partly overlapped, the later Northwest German departments.

Remarkably, the former Prussian province of Ostfriesland, together with Jever, Varel and the neutral mini-state Kniphausen, was left to Louis Bonaparte. In 1808, it was added to the Kingdom of Holland as the department of Oost-Friesland. Prior to incorporation, Count Willem Gustaaf Frederik Bentinck, former Lord of Kniphausen and Varel was so presumptuous as to send the king a draft decree to regulate the relations between his seigniories and the Kingdom of Holland. Bentinck opted for a kind of separate status, and spoke of Kniphausen's and Varel's population as 'his subjects'. Louis, however, made him clear that he, as sovereign, exercised full authority over Holland in its entirety. ${ }^{22}$ The Dutch government looked down upon the population of the East-Frisian Peninsula, therefore the local German-speaking population disliked the efforts of King Louis' collaborators to impose Dutch culture and institutions. For instance, Dutch officials considered the regional dialect as an inferior langue intermédiaire: 'the tongue of the East Frisians and Jeverans is actually a deformed and low Dutch', they claimed. ${ }^{23}$

\footnotetext{
${ }^{20}$ Ute Planert, 'Resistance to Napoleonic reform in the Grand Duchy of Berg, the Kingdom of Westphalia and the South German states', in: M. Broers, P. Hicks and A. Guimerá ed., The Napoleonic empire and the new European political culture (Basingstoke 2012) 149; Nicola P. Todorov, 'The Napoleonic administrative system in the Kingdom of Westphalia', in: M. Broers, P. Hicks and A. Guimerá ed., The Napoleonic Empire and the new European political culture (Basingstoke 2012) 174-175.

${ }^{21}$ Todorov, 'The Napoleonic administrative system', 183.

${ }^{22}$ Archives nationales, Paris, AF IV 1813, pièce 6.

${ }^{23}$ Archives nationales, AF IV 1816, pièce 13.
} 


\section{LAST STRONGHOLDS OF RepUblicanism}

As the Holy Roman Empire fell into disrepair, the urban elites of the three Hanseatic cities started nourishing a Hanseatic regionalism. In September 1806, urban representatives convened in Lübeck and founded a Hanseatic Federation. Nonetheless, they insisted that their association should be seen as a revival of the centuries-old ties between the three cities, based on their common history and interests, rather than a new political entity. But this made no impression on the French. On 6 November 1806 Napoleonic forces surrounded Lübeck, stormed the city gates, and defeated the fatigued Prussian troops in the streets. French soldiers plundered the neutral town, burn down houses, and harassed citizens. Subsequently, Bremen and Hamburg surrendered without a fight. Napoleon ordered the occupation of the three Hanseatic cities, as well the surrounding North Sea shores. ${ }^{24}$ Historian Katherine Aaslestad labels these events 'a turning point that brought the French Wars into [the Hanseatic] cities, harbors, warehouses, shops, and homes'. ${ }^{25}$ For instance, Hamburger lawyer Karl Gries wrote his traveling brother Johann Diederich that 'Lübeck's devastation has been our rescue [...] I tell you, our city is miraculously saved from the horrific fate of that unfortunate town [...] Where will it go with Germany, now that the last dam in which we had placed our hope to halt the thirst for power, is breached'. ${ }^{26}$

On 18 December 1806, Marshal Guillaume Marie-Anne Brune was appointed gouverneur-générale of the Hanseatic towns. Urban governments tried to maintain the appearance of political independence. They reassured each other that they were still in control, and the French governor was merely a military governor. In practice, the urban authorities were largely subordinate to the French, and foreign troops were constantly present. ${ }^{27}$ French (legal) reforms were initiated, but existing urban

\footnotetext{
${ }^{24}$ Katherine Aaslestad, 'Paying for war: Experiences of Napoleonic rule in the Hanseatic Cities', Central European History 39 (2006) 648-649. https://doi.org/10.1017/ S0008938906000215; Georges Servières, L'Allemagne française sous Napoléon Ier, d'après des documents inédits tirés des Archives Nationales et des Archives des Affaires Étrangères (Paris 1904) 88-90.

${ }^{25}$ Aaslestad, 'Paying for war', 645.

${ }^{26}$ Karl Gries to Dietrich Gries, 16 November 1806. Heinrich Reincke, 'Aus dem Briefwechsel von Karl und Diederich Gries, 1796-1819', Zeitschrift des Vereins für Hamburgische Geschichte 25 (1924) 244.

${ }^{27}$ Burghart Schmidt, Hamburg im Zeitalter der Französischen Revolution und Napoleons (1789-1813) (Hamburg 1998) 328-330.
} 
institutions were basically left intact. Quartering French soldiers was, of course, unpleasant; but it could have been worse, according to Karl Gries (now a member of the French judiciary). Also in daily life, the changes were not that dramatic, Gries claimed-apart from less feasts and luxury due to the circumstances. ${ }^{28}$ Quickly, Napoleon needed his soldiers elsewhere; remaining occupying forces were mostly 'good-natured Dutchmen'. According to Gries, the self-imposed austere lifestyle made way for a little more enjoyment of life. ${ }^{29}$ Yet, most citizens had a harder time than Gries, being forced to feed occupying troops, and provide officers with monetary allowances. And the financial burden increased. ${ }^{30}$

In the years 1808-1809 Napoleon's attention was directed toward other parts of Europe. The Fifth Coalition War was convincingly won. The subsequent Treaty of Schönbrunn, which was signed on 14 October 1809 , placed Europe almost entirely under Napoleonic rule, either directly or indirectly. However, it did not seem Napoleon's intention to deprive the Hanseatic cities of their semi-autonomous status and turn them into departments.

Napoleon was growing frustrated with the military weakness of Louis' army and continuing illegal trade with England. After the failed British invasion of the island of Walcheren in the summer of 1809 (the British suffered great losses, mostly due to bad hygienic conditions and spoiled drinking water), Napoleon summoned his brother to Paris. Walcheren was incorporated in December 1809. Dutch territories south of the Rhine followed in March 1810. Louis Bonaparte hoped this sacrifice would guarantee the independence of his reduced kingdom. ${ }^{31}$ Napoleon had also forced his brother to allow French custom officials in his kingdom, and the troops of Marshal Nicolas Oudinot slowly advanced toward Amsterdam. The dismantlement of the Kingdom of Holland came as no surprise. Some Dutchmen assumed they would be better off as imperial subjects. Perhaps incorporation could lead to improvements, such as the creation of a

\footnotetext{
${ }^{28}$ Karl Gries to Diederich Gries, 18 February 1807. Reincke, 'Aus dem Briefwechsel', 246-248.

${ }^{29}$ Karl Gries to Diederich Gries, 1 August 1807. Ibid., 248.

${ }^{30}$ Aaslestad, 'Paying for war', 652.

${ }^{31}$ Archives nationales, AF IV 1729, dossier 2, pièces 134-135; Nationaal Archief, The Hague, Staatsraad 1805-1810, inv. no. 107c.
} 
uniform judicial system, financial benefits, a large free trade area, and a lower tax burden. ${ }^{32}$

\section{The InCOrporation of THE NeTHERLANDS AND Northwest Germany}

When Louis Bonaparte abdicated and fled on 2 July 1810, Oudinot took control of the capital and Napoleon formally incorporated the remainder of the Kingdom of Holland a week later. Napoleon ordered his confidant Charles-François Lebrun to Amsterdam. As 'Lieutenant General', Lebrun was to take over the duties of Louis and oversee the transition to French rule. ${ }^{33}$ Lebrun initially objected to his appointment. He considered himself to be too old and pointed out that his acts as Governor in Genoa (where he had been gouverneur-général in 1805) had not been completely satisfactory to all parties. ${ }^{34}$ Napoleon waved aside Lebrun's objections. Within a few days, Lebrun arrived in Amsterdam. Fifty years earlier, as a student, Lebrun was shocked that the once-dynamic port city had lost much of its glory. ${ }^{35}$

Charles-François Lebrun had to ensure the government and military swore allegiance to the Emperor, and keep an eye on the budget of the former Kingdom. The Decree of Rambouillet (8/9 July 1810), the official incorporation act, had been short. Provisionally, the structure of the Kingdom of Holland was largely kept intact. Lebrun supervised the former Ministers, who had to remain at their post until 1811, just like their subordinates. Amsterdam officially became the third imperial capital, after Paris and Rome. It was determined that there would be just a few immediate changes. ${ }^{36}$ Firstly, the Dutch customs was united with the French customs. Secondly, as a retribution for illegal trade, all (smuggled) colonial goods found were taxed 50 percent. ${ }^{37}$ Thirdly, feared by many, interest payments on the public debt were cut by two thirds (the so-called

\footnotetext{
${ }^{32}$ Johanna W. A. Naber, Overheersching en vrijwording : geschiedenis van Nederland tijdens de inlijving bij Frankrijk, juli 1810-november 1813 (Haarlem 1913) 23-24.

${ }^{33}$ Napoleon to Lebrun, 8 July 1810. Jourdan ed., Correspondance générale X, no. 23927.

${ }^{34}$ Auguste De Caumont la Force, L'architrésorier Lebrun, gouverneur de la Hollande, 1810-1813 (Paris 1907) 2.

${ }^{35}$ A. E. M. Ribberink, 'Lebrun en de homines novi', Nederlands Archievenblad XC (1986) 133.

${ }^{36}$ Bulletin des lois, 4e serie XIII (Paris 1811) 331; Archives nationales, F17, 1098, pièce 133.

${ }^{37}$ Naber, Overheersching en vrijwording, 25-26.
} 
tierrering). Citizens would receive only one third of the interest they deserved. This would further contribute to the economic malaise of the Dutch departments. Although no interest on public debts had been paid since 1808, moneylenders, often merchants, lost their trust in the government, further stagnating the economy. ${ }^{38}$

In this transitional phase, Lebrun had to prepare the Dutch departments for integration, keep Napoleon informed and make sure all imperial orders were executed. He received many instructions from the Emperor, sometimes three to four letters per day. Given the Emperor's ambitions, Lebrun had to evaluate which of Napoleon's ideas could be implemented swiftly. ${ }^{39}$ Also, the new subjects had to be reassured. Lebrun comforted disillusioned Dutchmen that, now that the Republic's days of glory were over, integration in the Empire was the best alternative. ${ }^{40}$

As for Northwest Germany, Napoleon was pondering of appointing his loyal Marshal Louis Nicolas Davout to oversee the incorporation. Previously, Davout had been Governor of the Duchy of Warsaw, created in 1807 from former Prussian lands. So, like Lebrun, Davout had obtained experience in the Empire's peripheries. Almost all of 1810, Davout had been in Paris in the circles of the Emperor and his ministers. He, therefore, had witnessed the dealings with the King of Holland. French troops in Germany were still scattered along the North Sea coast after defending Holland. With a reorganized army Napoleon wanted to assert his power in all German territories and eventually in Russia. In this plan, a key role was assigned to Davout. ${ }^{41}$ Marshal Davout had to coordinate his reorganization with the customs authorities in Germany to work efficiently and supervise any corrupt customs officers. ${ }^{42}$ When reforms did not go smooth enough to the Emperor's taste, Davout was reminded all French troops in

${ }^{38}$ J. L. van Zanden and Arthur van Riel, The structures of inheritance: The Dutch economy in the nineteenth century. The Princeton economic history of the Western world (Princeton 2004) 72-73.

${ }^{39}$ A.-C. Lebrun, 'Notice biographique', in: A.-C. Lebrun ed., Opinions, rapports, et choix d'écrits politiques de Charles-François Lebrun, duc de Plaisance (Paris 1829) 131.

${ }^{40}$ Annie Jourdan, 'La réunion de la Hollande à la France: histoire d'un processus', in: F. Antoine et al. ed., L'Empire napoléonien. Une expérience européenne? (Paris 2014) 142.

${ }^{41}$ Ch. De Mazade ed., Correspondance du maréchal Davout, prince d'Eckmühl. Ses commandements, son ministère, 1801-1815. Tome troisième (Paris 1885) 174-175.

${ }^{42}$ Napoleon to Davout, 28 September 1810. Jourdan ed., Correspondance générale X, no. 24702 . 
Germany were under his command and he was, therefore, responsible for the progress. ${ }^{43}$

In Northwest Germany, it had become clear that the French were increasing their presence. As in the Netherlands, this was not perceived unequivocally. In Hamburg, some took the view that the Senate should have resigned a long time ago, as it no longer possessed any genuine authority; others welcomed that the councilors held on to their office, but concluded that in the end there was no other option but to submit to the French. Despite the ever-increasing rumors, the news of the incorporation came as a surprise. On 7 December, Davout was first referred to by Napoleon as 'gouverneur général des villes hanséatiques' ${ }^{44}$ The population, however, was informed as late as 18 December $1810 .{ }^{45}$ Changes had been expected, but not an incorporation. Some were mildly positive about the change in political system, hoping an improvement in economic prospects within the Empire, or, in the case of religious minorities, more equality. But overwhelming majority of citizens regretted the loss of traditional autonomy, especially the urban lower classes reacted increasingly annoyed to the entailing negative economic and social developments. The strengthening of the military presence in Northern Germany and the implementation of the October Decrees marked the beginning of a new phase in Napoleon's enforcement of the Continental System. Severe clashes took place between French gendarmes, who tried to confiscate goods, and the lowest social classes. ${ }^{46}$

Also, the concerned German princes had to be notified their principalities would soon be disbanded. This involved little clashes or personal dramas. Two categories of states were involved: Napoleonic vassal monarchies (Berg and Westphalia) and principalities ruled by the German Houses of Oldenburg, Arenberg, and Salm. The affected princes were politely informed of the loss of their country or a portion thereof. Concerning the former category: Napoleon saw the appropriation of parts of the domains belong to his family members as more or less a formality. In August 1810, Napoleon had prepared the taking of the German North Sea Coast. Not seeing his brother Jérôme Bonaparte as an equal, he considered that he

\footnotetext{
${ }^{43}$ Napoleon to Davout, 4 October 1810. Ibid., 24780.

${ }^{44}$ Napoleon to Davout, 7 December 1810. Ibid., 25447.

${ }^{45}$ Karl Gries to Diederich Gries, 28 March 1811. Reincke, 'Aus dem Briefwechsel', 255.

${ }^{46}$ Schmidt, Hamburg, 327, 422-423.
} 
'could do as he pleased' with the Kingdom of Westphalia. ${ }^{47}$ The Emperor ordered his troops to occupy the north of the kingdom and his brother to withdraw Westphalian troops. ${ }^{48}$ Jérôme was not pleased, but did not stop his brother. Bordering Westphalia, the Grand Duchy of Berg was formally ruled by Napoleon's nephew Napoléon Louis Bonaparte (son of former Dutch king Louis), but in effect, it was administrated by Jacques Claude Beugnot. Ceding a part of the Grand Duchy to the Empire was also a formality. Plus, because the previous ruler Murat had introduced high taxes, the local population looked forward to integration into France, with its relatively better fiscal climate. ${ }^{49}$

Equally straightforward was the taking of the possessions of the Duke of Aremberg, and the Princes of Salm-Salm and Salm-Kyrburg, enclaves within Hanover. Duke Prosper Ludwig von Arenberg, a brother-in-law of Joséphine de Beauharnais, was closely associated with the Empire. At that time, he was serving as an officer in the Grande Armée in Spain, leaving the actual governing of his Duchy to a Governor. As early as 1808 he had indicated he was willing to negotiate over the future of the Dutch of Arenberg. For his territorial losses, Von Arenberg was financially compensated and received the French title of Duke. ${ }^{50}$ Prince Konstantin zu SalmSalm and Prince Friedrich IV zu Salm-Kyrburg jointly ruled the Principality of Salm. Like von Aremberg, they were willing to relinquish their sovereignty. They were eventually compensated financially and admitted as dukes to the French nobility. ${ }^{51}$

The incorporation of the Grand Duchy of Oldenburg, however, was politically sensitive. To begin with, Grand Duke Peter Friedrich Wilhelm was an uncle of the Czar and the French emperor had to inform his Russian counterpart as well. Due to mental illness of the Grand Duke, his cousin Peter Friedrich Ludwig acted as head of state. He was not intent on leaving his country. After Peter Friedrich Ludwig had declined the first offer from Napoleon (namely Erfurt), Napoleon decided that the area had to be occupied. After diplomatic negotiations, Von Keverberg (a promising

\footnotetext{
${ }^{47}$ Napoleon to Champagny, 4 August 1810. Jourdan ed., Correspondance générale X, no. 24220.

${ }^{48}$ Napoleon to Clarke, 18 August 1810; Napoleon to Jérôme Bonaparte, 18 August 1810. Ibid., 24346; 24351.

${ }^{49}$ Antoinette Joulia, 'Ein französischer Verwaltungsbezirk in Deutschland: Das Oberemsdepartement (1810-1813)', Osnabrücker Mitteilungen 80 (1973) 44.

${ }^{50}$ Ibid., 43-44.

${ }^{51}$ Servières, L'Allemagne française sous Napoléon, 222.
} 
subprefect from Westphalia) was put forward, who completed the delicate task of persuading the duke, without endangering the Franco-Russian relations. Formally, the Grand Duchy ceased to exist on 28 February 1811; the ducal family had left for Russia the day before. ${ }^{52}$

\section{Napoleon's Drott de Conquête}

Napoleon's view on the newly acquired northern territories is telling, specifically, his discourse on pays conquis or pays réunies. In the technical language of the time, distinctions were made between pays conquis and pays réunies, the latter comprising territories integrated into France. ${ }^{53}$ Pays réunies should genuinely form part of the Empire and be treated on an equal footing with Old France, such as the system of governance. Pays conquis, however, were not considered to be integral parts of the Empire.

In Amsterdam, Charles-François Lebrun had been charged with the duty of selecting prominent Dutchmen to be sent to Paris to prepare the réunion. In August 1810, a committee of 15 Dutch notables (the 'Conseil pour les affaires de Hollande') went to Paris to provide the French government there with useful information and proposals to efficiently integrate the Netherlands. Another 15 deputies-from the army, the Council of State and the municipal council of Amsterdam-were added to this committee. ${ }^{54}$ It inventoried the differences between Dutch and French governance, first and foremost the administration, but also many other aspects such as the judicial system, finances, police, and armed forces. Also, a decision had to be made about which Dutchmen should become members of central state bodies. ${ }^{55}$ During the daytime, there were long talks with the Emperor and his ministers. Each evening there were informal dinners and meetings. The Dutch diplomats regarded their French colleagues as more reliable partners than former King Louis Bonaparte. Now they could do business directly with the imperial government and stress that, in their opinion, a drastic imposition of French rule was

\footnotetext{
${ }^{52}$ Joulia, 'Ein französischer Verwaltungsbezirk', 44-45.

${ }^{53}$ Geoffrey Ellis, The Napoleonic empire (2nd ed.; Basingstoke 2003) 90.

${ }^{54}$ Th. Jorissen, 'De commissie van 22 juli 1810 te Parijs', Bijdragen voor Vaderlandsche Geschiedenis en Oudheidkunde Nieuwe Reeks deel IX (1877) 67.

${ }^{55}$ Lebrun, 'Notice biographique', 130.
} 
unwanted. Many of the committee members would later be appointed to high posts. ${ }^{56}$

Napoleon's attitude toward the Dutch was ambiguous. Napoleon noted that there was a major difference between the incorporation of a small territory and incorporating an entire nation. When incorporation concerned a single new department, Napoleon stressed that he could make no exceptions. However, he had received positive reports from Lebrun and other informants. Holland was not a pays conquis in Napoleon's eyes. He congratulated the Dutch on having many good institutions, which did not have to be replaced. Integration could be taken gradually, paying attention to local customs. He clarified that he did not intend to send a great deal of French officials. ${ }^{57}$ Nor did all aspects of governance become strictly French. For instance, the Dutch commission successfully lobbied for preservation of Dutch as an administrative language. ${ }^{58}$ But Dutch should not be the dominant language, Lebrun emphasized: 'the réunion will be imperfect when the published public acts continue to be written in a language different from ours'. ${ }^{59}$

However, the Emperor also looked down on Dutch administrators and politicians. On occasions, Napoleon was even aggressive. During an audience, the Emperor praised Dutch national identity but had contempt for many members of the elite. He frequently made committee members understand good and proper that he had every right to do as he pleased with his new subjects. In that sense, the Dutch had to be just as obedient as other conquered lands. Napoleon argued that since 1787, when Prussian armies had expelled the Patriots, Dutch independence was fiction: 'I hold you by right of conquest, and this is indeed the most sacred right; do not speak to me of independence; since the Prussians invaded your territory, your independence has been lost' ${ }^{60}$ This right of conquest characterized Napoleonic diplomatic philosophy. Talleyrand legitimized the droit de conquête of the Emperor. In previous centuries, Talleyrand reasoned, the keeping of a balance of power in Europe was increasingly

\footnotetext{
${ }^{56}$ Marie Elisabeth Kluit, Cornelis Felix van Maanen. Tot het herstel der onafhankelijkheid, 9 september 1769-6 december 1813 (Groningen 1953) 293-327.

${ }^{57}$ Jorissen, 'De commissie van 22 juli 1810 te Parijs', 74-75.

${ }^{58}$ D. van der Horst, 'Cornelis Felix van Maanen, dienaar van vele heren', Holland Historisch Tijdschrift 32 (2013) 8.

${ }^{59}$ Archives nationales, F17 1092, dossier 1, pièces 29-30.

${ }^{60}$ Jorissen, 'De commissie van 22 juli 1810 te Parijs', 76-77.
} 
kept not by negotiations and international treaties, but by warfare. The stability of Europe depended on it. ${ }^{61}$

Concerning the right of conquest, it is relevant to compare Napoleon's attitude toward the Netherlands with his attitude toward Northwest Germany. Strikingly, in general, the French were less outspoken when it came to the German-speaking lands in the Northwest. Early October, Emperor Napoleon still referred to the region as provinces réservées over which Marshall Davout was charged with enforcing law and order. ${ }^{62}$ It seems the French authorities in Germany were more occupied with reorganizing the German armies and other pressing military matters.

On 10 December 1810 Napoleon sent the Senate a message on the incorporation of the Netherlands and Northwest Germany. Foremost, it was presented as a defensive action against the politics of the British government. This region could also be useful to dig a canal to the Baltic sea, thus circumventing the British maritime presence. ${ }^{63}$ Minister of External Affairs, Jean-Baptiste de Nompère de Champagny (a hardliner concerning imperial expansion) also presented a picture that was opposite to that many Europeans had. According to him, the 'conciliatory' Napoleon Bonaparte had always given in on his conquests for the sake of peace between the major forces. Champagny underlined that earlier expansions of France, such as the annexing of Belgium and the secularizations in Germany, had strengthened the power of Prussia and Austria, and in fact, it was France who had acted modestly in preceding years. He saw conquest as a reaction to foreign aggression. Incorporation of Northwest Germany was necessitated by circumstances. With that Champagny pointed at possible economic benefits of canalization, also to avoid the British fleet on the North Sea and thus re-establishing the 'freedom of the seas' which had been threatened by the British. ${ }^{64}$

Three days later, spoke Senator Charles-Louis Huguet de Sémonville, former French ambassador in the Batavian Republic. As rapporteur parlementaire, he had reported on the legislation concerning the

\footnotetext{
${ }^{61}$ Emmanuel de Waresquiel, 'Talleyrand, une vision européenne', in: T. Lentz ed., Napoléon et l'Europe (Paris 2005) 134-135.

${ }^{62}$ Napoleon to Clarke, 4 October 1810. Jourdan ed., Correspondance générale X, no. 24764 .

${ }^{63}$ Napoleon to the Senate, 10 December 1810. J. Mavidal and E. Laurent ed., Archives parlementaires de 1787 à 1860. Recueil complet des débats législatifs et politiques des chambres françaises XI (Paris 1867) 3.

${ }^{64}$ Champagny to Napoleon, 10 December 1810. Ibid., 3-5.
} 
incorporation of allied states into the Empire. In his eyes the northern regions had to choose between rival powers France and Great Britain. The North had been a 'shallop' between the grand warships of the French and British but now had sided with the Empire. The Batavians, who had suffered so much, were reunited with their Belgian brothers. But De Sémonville had no elegant analogy for the German situation. Incorporating Northwest Germany was presented as a geopolitical fait accompli. ${ }^{65}$

Like the Dutch, the new Northwest-German subjects sent a joint delegation to France, though not prior to the official incorporation, but afterward. ${ }^{66}$ Davout advised the deputies to return home quickly, since their stay in France might still give rise to unjustified hopes. Spokesman, and former Syndicus, Hermann Doormann on 17 March 1811 paid tribute to Napoleon. When Doormann spoke of the Hanseatic cities as traditional competitors of England and friends of France, this was more his personal view than the general opinion. Nevertheless, Doormann defended the interests of the Hanseatic cities, recalled their merits, and, between the lines, pleaded to preserve the positive achievements of the past. ${ }^{67}$ In his speech, Doormann pointed at the illustrious history of the Hanseatic cities, as a civilizing force in Northern Europe. There were historical connections with France, dating back to Charlemagne. Doormann underlined that the Germans were willing to subject to the will of the Emperor, without seeing themselves as a territoire vulgaire, or acquisation obscure. They have good morals, a rich history and are industrious-all in 'a fortunate mix of aristocracy without morgue, and democracy without storms. The main weakness of the Hanseatic cities was the deplorable state of commerce, therefore Doormann expressed the hope to start trading with the southern parts of the Empire, implicitly arguing against internal trade barriers. He carefully presented this as a compensation. ${ }^{68}$

Emperor Napoleon replied that with the dissolution of the Holy Roman Empire, the status of the imperial cities had become unclear. Initially, he had wanted to unify then within a separate state, but without navy, it would be a defenseless independent state. Incorporation had to be seen within the context of European warfare, not as a long-wished imperial ambition. The Decrees of Berlin and Milan (an elaboration of the Decree of Berlin)

${ }^{65}$ Sémonville to Napoleon, 13 December 1810. Ibid., 20-21.

${ }^{66}$ Napoleon to Davout, 12 March 1811. Jourdan ed., Correspondance générale X, no. 26202.

${ }^{67}$ Schmidt, Hamburg, 460-461.

${ }^{68}$ Doormann to Napoleon, 17 March 1811. Lewis Goldsmith, Recueil de décrets, ordonnances, traités de paix, manifestes, proclamations, discours, orc. [...] 4 (London 1813) 591-593. 
together formed the loi fondamentale of the Empire, the droit public de mon empire, Napoleon stressed. He opposed states that had the courage to defy these imperial fundaments. Although Napoleon's words were reasonably friendly, he indirectly associated the Hanseatic cities with such states. He was willing to stimulate trade, so he said, but first, the maritime war had to end. The Germans had to wait the 'general peace', a common pretext of Napoleon when allied or incorporated nations make certain pleas. The Hanseatic cities were urged to actively cooperate with pacifying the seas by helping to enlarge the naval power of the Empire. ${ }^{69}$ So, in the short term, the Germans were not promised free trade.

Surely, public speeches such as the above, which were printed in the newspapers, had public relations purposes. Napoleon, a calculating pragmatist, was not a man for manifestos. He favored the 'système du moment'. ${ }^{70}$ Nevertheless, above arguments come close to a declaration of intentions with Northern Europe. Illustratively, Napoleon instructed Davout to send the Duke Friedrich Franz of Mecklenburg (the last principality that had joined the Confederation of the Rhine) a copy of his discourse, to make clear, that the Duke clear had to submit to the 'system of France'. ${ }^{71}$ The Hanseatic representatives remained in Paris some time, attending formal ceremonies, but Davout quickly ordered them back. He feared that the activities of the improvised delegation, might have a bad influence on public moral. ${ }^{72}$ Indeed, the delegates do not seem to have been popular. For instance, Karl Gries considered suspected that Hermann Doormann headed the delegation perhaps more due to his knowledge of the French language, than his diplomatic capabilities. ${ }^{73}$

Napoleon's words to members of both committees were amicable and severe. To grasp the relatively positive nature of his words, it is significant to compare them to Napoleon's response to the delegation of the new Lippe departement, that largely consisted of the former Prince-Bishopric of Münster. This area, due to protests of the local elite, had been separated from the Dutch departments by Lebrun. The Emperor characterized the Northwest German region rather negatively. Münster had been in a

${ }^{69}$ Ibid., 593-594.

${ }^{70}$ Annie Jourdan, L'empire de Napoléon (Paris 2000) 152-153.

${ }^{71}$ Napoleon to Davout, 24 March 1811. Jourdan ed., Correspondance générale X, no. 26380.

${ }^{72}$ Servières, L'Allemagne française sous Napoléon, 254-255.

${ }^{73}$ Karl Gries to Diederich Gries, 27 March 1810. Reincke, 'Aus dem Briefwechsel', $253-254$. 
deplorable state of ignorance and superstition, Napoleon claimed. He presented its inclusion in the Empire, together with Holland and the Hanseatic departments, as an act of mercy. ${ }^{74}$

\section{Pars Réunies, Under Conditions}

The concepts of droit de guerre and droit de conquête progressively legitimized French dominance. Any violation of the Blocus, being the Empire's 'public law', should serve as a legal justification for incorporation. In this argumentation, the Emperor was not an aggressor, but the one who stood up for nations that de facto had already lost their independence for a long time. In this light, it is tempting to highlight Napoleon's, often positive, words for the Dutch and the relative French lack of interest for Northwest Germany, implying that the French only were preoccupied with winning over the Dutch at the start of the incorporation. Indeed, prominent Dutch politicians were sent to Paris for formal and informal discussions, and the need to take Dutch institutions and traditions into account was stressedelements less present in official discourse on Northwest Germany, which would suggest the German territories were more of a pays conquis in the Parisian minds. That Napoleon for some time referred to Northwest Germany as provinces réservées would also confirm this interpretation. However, this would be a gross simplification. Napoleon's approach to the Northwest Germans definitely bears witness of a certain acknowledgement of a Hanseatic 'nation', or regional identity that transcended the urban sphere. Undeniably, Napoleon looked down on individual northern merchants and officials, whom he considered to be conceited and arrogant. Yet, these feelings were not necessarily extrapolated to the peoples in general-certainly not by all Frenchmen in the North.

Accordingly, the 'uniqueness' of both Dutch and German regions was acknowledged, albeit in different ways. As for the Dutch, their national identity and 'modernity' were not put into question, yet, the fact that they needed to be part of the Empire (like, for instance, many Italians) was a given fact. As for Northwest Germany, the Napoleonic government made clear that its incorporation was less 'logical': inclusion of these former parts of the Holy Roman Empire was of a pragmatic nature, much more so than in the Dutch case. Geopolitical circumstances had necessitated the

\footnotetext{
${ }^{74}$ Napoleon to the delegation of the Lippe department, 18 August 1811 Correspondance de Napoléon Ier; publiée par ordre de l'empereur Napoléon III. Tome 22 (Paris 1867) no. 18048 .
} 
incorporation, it was argued. Nonetheless, Napoleon increasingly embraced the idea of an imperial system as guiding principle for Europe, in which he became the spiritual successor of the Holy Roman Emperors. In an Empire, a Dutch and Hanseatic nation could partially persist, as long as the interests of Old France were not harmed. In other words: the Netherlands and Northwest Germany became pays réunies, under conditions.

What was not recognized at the time was that the actual integration process would be much more challenging. The genesis, composition and internal dynamics of the intermediary bodies of governance in Amsterdam and Hamburg that had to oversee the integration process, will be discussed in the next chapter.

Open Access This chapter is licensed under the terms of the Creative Commons Attribution 4.0 International License (http://creativecommons.org/licenses/ by $/ 4.0 /)$, which permits use, sharing, adaptation, distribution and reproduction in any medium or format, as long as you give appropriate credit to the original author(s) and the source, provide a link to the Creative Commons licence and indicate if changes were made.

The images or other third party material in this chapter are included in the chapter's Creative Commons licence, unless indicated otherwise in a credit line to the material. If material is not included in the chapter's Creative Commons licence and your intended use is not permitted by statutory regulation or exceeds the permitted use, you will need to obtain permission directly from the copyright holder.

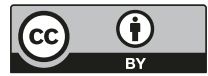

